\title{
WYBRANE UWARUNKOWANIA OBCIĄŻENIA OPIEKUNÓW NIEFORMALNYCH WEDLUG COPE-INDEKS W OPIECE DOMOWEJ NAD PACJENTAMI Z DEFICYTEM SPRAWNOŚCI FUNKCJONALNEJ
}

\section{SELECTED FACTORS CONDITIONING A NEGATIVE IMPACT ON INFORMAL OF HOME CARE PATIENTS WITH FUNCTIONAL MOBILITY DEFICITS ACCORDING TO THE COPE-INDEX}

\author{
Agnieszka Bartoszek, Barbara Ślusarska, Alina Deluga, Grzegorz Józef Nowicki, \\ Katarzyna Piasecka, Katarzyna Kocka, Hanna Kachaniuk
}

Zakład Medycyny Rodzinnej i Pielęgniarstwa Środowiskowego, Wydział Nauk o Zdrowiu, Uniwersytet Medyczny w Lublinie

DOI: https://doi.org/10.20883/ppnoz.2019.27

STRESZCZENIE

Wstęp. Wystąpienie choroby przewlekłej z towarzyszącym deficytem sprawności funkcjonalnej u jednego z członków rodziny powoduje wzrost zapotrzebowania na świadczenia z zakresu opieki formalnej i nieformalnej nad pacjentem. Konsekwencją sprawowania długotrwałej opieki nad chorym w środowisku domowym jest obciążenie opiekuna nieformalnego.

Cel. Analiza wybranych uwarunkowań obciążenia opiekunów nieformalnych w opiece domowej nad pacjentami z deficytem sprawności funkcjonalnej w oparciu o czynniki socjodemograficzne oraz organizacyjno-zdrowotne.

Materiał i metody. W badaniu wzięło udział 150 opiekunów nieformalnych opieki domowej i 149 pacjentów z chorobami przewlekłymi z deficytem sprawności funkcjonalnej. Do oceny obciążenia opiekunów nieformalnych zastosowano narzędzie przesiewowe do rozpoznawania potrzeb opiekunów rodzinnych - kwestionariusz COPE-Indeks.

Wyniki. Średnia wartość obciążenia opiekunów w subskali Negatywny Wpływ Opieki (NWO) wyniosła 11,80 (SD = 3,75) i świadczy o przeciążeniu opieką oraz wzrasta wraz z długością czasu trwania sprawowanej opieki $(p<0,01)$ oraz pogorszeniem stanu zdrowia opiekuna $(p<0,01)$. W subskali Pozytywna Wartość Opieki (PWO) średnia wartość wyniosła 13,71 (SD = 2,07), a w obszarze Jakości Wsparcia (JW) 12,4 (SD = 2,69). Domeny PW0 i JW pozostają w istotnej korelacji z wiekiem pacjenta, płcią żeńską opiekuna, wzrostem czasu opieki oraz wsparciem uzyskanym od innych osób ( $p<0,01)$.

Wnioski. Opiekunowie nieformalni odczuwają obciążenie w związku z opieką nad pacjentem z deficytem sprawności funkcjonalnej w opiece domowej, ale też odczuwają satysfakcję w zakresie pozytywnej wartości opieki i jakości wsparcia. Obciążenie opiekuna koreluje z wiekiem chorego oraz czasem trwania opieki, a także stanem zdrowia opiekuna.

Słowa kluczowe: obciążenie, opiekun nieformalny, opieka domowa, deficyt sprawności funkcjonalnej.

ABSTRACT

Introduction. The occurrence of chronic disease with functional mobility deficits in a family member results in an increased need for providing formal and informal patient care services. As a result of a long-term patient care in a home environment, a negative impact is imposed on informal carers.

Aim. An analysis of selected factors conditioning a negative impact on informal carers of home care patients with functional mobility deficits, based on social and demographic, as well as organizational and health factors.

Material and methods. The survey was conducted among 150 informal home carers and 149 chronic disease patients with functional mobility deficits. The assessment of the negative impact on informal carers was carried out using a screening tool which allows identifying the needs of home carers, that is the COPE-Index questionnaire.

Results. The average value of negative impact on home carers in the negative impact subscale was $11.80(S D=3.75)$, which suggests that provision of care results in overburdening of carers which becomes exacerbated with time $(p<0,01)$, and leads to the deterioration of caregivers' health $(p<0,01)$. The average value in the positive value subscale was $13.71(S D=2.08)$, and the quality of support subscale was $12.4(S D=2.69)$. The results indicated by the positive value and quality of support subscales showed a significant correlation with the age, the fact that the caregiver was a female, the increase of time of care and the availability of support of other persons $(p<0,01)$.

Conclusions. Although, the informal carers experience negative impact related to providing home care to patients with functional mobility deficits, they also stress the positive emotions in terms of positive value of care and quality of support. The burden on the carer correlates with the patient's age and period of care, as well as the physical and mental condition of the carer.

Keywords: negative impact, informal carer, home care, functional mobility deficits. 


\section{Wstęp}

Wystąpienie choroby przewlekłej z towarzyszącym deficytem samodzielności funkcjonalnej u jednego z członków rodziny wpływa na jej funkcjonowanie w istotny sposób [1]. Niska sprawność funkcjonalna pacjentów pozostających w domowej opiece długoterminowej jest przyczyną wielu problemów zdrowotnych samego pacjenta, ale także problemów związanych z zapewnieniem opieki w środowisku domowym. Taka sytuacja powoduje wzrost zapotrzebowania na świadczenia z zakresu opieki formalnej i nieformalnej nad pacjentem. Jedną z form opieki formalnej w polskim systemie opieki zdrowotnej jest pielęgniarska opieka długoterminowa, którą mogą być objęci pacjenci w środowisku domowym uzyskujący w ocenie skalą Barthel od 0 do 40 punktów i posiadają skierowanie od lekarza ubezpieczenia zdrowotnego [2]. Poza tymi świadczeniami podopieczni z deficytem sprawności funkcjonalnej w środowisku domowym pozostają także pod opieką opiekunów nieformalnych. Opieka nieformalna jest pojęciem szerszym niż opieka rodzinna, gdyż poza członkami rodziny w opiekę mogą być zaangażowani znajomi, sąsiedzi, wolontariusze oraz osoby ze środowisk lokalnych [3]. Przeważająca część osób niesamodzielnych w Polsce otrzymuje pomoc i opiekę głównie ze strony rodziny i krewnych [4] choć według badań europejskich tendencja jej udziału jest malejąca [5].

W polskich nielicznych badaniach dotyczących oceny sprawności funkcjonalnej z użyciem skali Barthel pacjentów objętych domową długoterminową opieką pielęgniarską ponad połowę badanych stanowią pacjenci z niską sprawnością funkcjonalną (w skali Barthel 0-40 pkt) tj. wymagający dużego zakresu pomocy w wykonywaniu podstawowych czynności codziennych lub niezdolni do samoopieki $[6,7]$.

Sprawowanie długotrwałej opieki nieformalnej nad pacjentem z niską sprawnością funkcjonalną pociąga za sobą wiele konsekwencji dla opiekuna w postaci obciążenia psychicznego, fizycznego i materialnego [8], które pogarszają ich jakość życia, w tym funkcjonowanie w obszarze społecznym, rodzinnym i zawodowym [9]. Opiekunowie rodzinni/nieformalni mają wiele różnych obowiązków w opiece: świadczenie usług pielęgnacyjnych, leczniczych i transportowych; zaspokojenie potrzeb emocjonalnych oraz udzielanie wsparcia psychologicznego podmiotom opieki. Szeroki zakres obowiązków wykonywanych przez opiekunów nieformalnych na rzecz niesprawnych członków rodziny często przytłacza ich, przyczyniając się do zmniejszenia ich zatrudnienia lub godzin pracy [10, 11], jak również pogorszenia zdrowia fizycznego i psychicznego, a tym samym zmniejszenia dobrostanu wszystkich człon- ków rodziny [12]. Negatywny wpływ opieki nie jest uznawany za chorobę lub dysfunkcję opiekuna nieformalnego, chociaż czasami jest porównywany do "cichej choroby" lub "cierpienia w ciszy" $i$ jest często pomijany przez klinicystów skupionych wyłącznie na problemach zdrowotnych pacjentów potrzebujących opieki [13]. Na poczucie obciążenia przez opiekuna mają wpływ czynniki związane bezpośrednio z charakterystyką opiekunów (medyczne, psychologiczne, socjodemograficzne), dotyczące pacjenta (psychopatologiczny obraz choroby, osobowość) oraz czynniki środowiskowe i społeczne (wsparcie rodzinne) [14]. Opiekunowie, którzy są w zaawansowanym wieku, kobiety oraz opiekunowie mieszkający wspólnie z pacjentem doświadczają większego poczucia obciążenia niż opiekunowie młodzi, mężczyźni, a także ci, którzy mieszkają poza miejscem zamieszkania chorego. Wiele badań dowodzi, że najwyższego poziomu obciążenia doświadczają współmałżonkowie jako opiekunowie nieformalni $[15,16]$.

\section{Cel pracy}

Celem badawczym pracy była analiza wybranych uwarunkowań obciążenia opiekunów nieformalnych w opiece domowej nad pacjentami z deficytem sprawności funkcjonalnej w oparciu o czynniki socjodemograficzne oraz organizacyjno-zdrowotne.

\section{Materiał i metody}

\section{Projekt badań i uczestnicy}

Badania zostały przeprowadzone w pięciu publicznych zakładach opieki zdrowotnej w województwie lubelskim w okresie od września 2016 do lutego 2017 roku. Wywiad został przeprowadzony wśród opiekunów nieformalnych $(n=150)$ oraz pacjentów $(n=149)$ z chorobami przewlekłymi i deficytem sprawności funkcjonalnej, objętych opieką w warunkach domowych. Dane w wywiadzie bezpośrednim kolekcjonowały pielęgniarki $(n=18)$ podczas wizyt domowych. Pielęgniarki przed przystąpieniem do zbierania danych zostały zapoznane z projektem badania oraz przygotowane do zbierania danych zgodnie z przyjętą procedurą badania.

Kryterium doboru opiekuna było: pełnienie funkcji opiekuna nieformalnego/rodzinnego badanych pacjentów oraz wyrażenie zgody na udział w badanu. Kryterium doboru pacjentów objętych pielęgniarską domową opieką długoterminową stanowiły: deficyt sprawności funkcjonalnej chorego wg skali Barthel 0-85 pkt, prawidłowy stan umysłowy wg Skróconego Testu Sprawności Umysłowej (AMTS) powyżej 6 pkt, w wywiadzie chorobowym miazdżyca uogólniona (ICD-10 - 170), brak wspótistniejącej 
choroby nowotworowej i niewydolności nerek, dobrowolnie wyrażona zgoda na udział w badaniu.

\section{Narzędzia badawcze oceny obciążenia opiekunów nieformalnych}

W kwestionariuszu oceny opiekuna nieformalnego pacjentów z deficytem sprawności funkcjonalnej w opiece domowej uwzględnione zostały następujące dane socjodemograficzne: płeć, wiek, stan cywilny, zatrudnienie, stopień pokrewieństwa z podopiecznym; oraz dane organizacyjno-zdrowotne: odległość miejsca zamieszkania opiekuna od podopiecznego, samoocena stanu zdrowia opiekuna, doświadczenie związane z opieką nad podopiecznym w domu.

Do oceny obciążenia opiekunów nieformalnych/rodzinnych zastosowano kwestionariusz COPE Indeks. COPE Indeks jest wstępnym narzędziem przesiewowym do rozpoznawania potrzeb opiekunów i podkreśla subiektywną ocenę opiekuna jego sytuacji i okoliczności sprawowania opieki [17]. Narzędzie składa się z 15 pytań zawartych w trzech podskalach: Negatywny Wpływ Opieki (NWO) - 7 pytań, Pozytywna Wartość Opieki (PWO) - 4 pytania oraz Jakość Wsparcia (JW) - 4 pytania. Ostatnie pytanie skali COPE Indeks jest pytaniem otwartym i brzmi: Czy jest jeszcze coś, o czym chciałby Pan/i nam powiedzieć? Przeciążenie opieką nad pacjentem w obszarze NWO posiada zakres 7-28 pkt, pozostałe domeny: PWO i JW posiada zakres 4-16 pkt. Podskale nie posiadają referencyjnych wartości progowych, ponieważ każda z domen COPE Indeks stanowi pewną ciągłość. Zostały zatwierdzone jako wewnętrznie spójne, z wykorzystaniem dużej próby opiekunów nieformalnych pobranych z sześciu krajów europejskich, w tym dla Polski. Współczynnik rzetelności alfa Cronbacha dla narzędzia COPE Indeks wynosi 0,82 [17].

\section{Dane pacjentów z deficytem sprawności funkcjonalnej w opiece domowej}

Do oceny podstawowych czynności życia codziennego zastosowano skalę Barthel. W skali tej pod uwagę bierze się czynności codziennego życia, takie jak spożywanie posiłków, przemieszczanie się, utrzymanie higieny osobistej, korzystanie z toalety, kąpiel całego ciała, poruszanie się po płaskiej powierzchni, wchodzenie po schodach, ubieranie się, kontrolowanie stolca i moczu. W zależności od zakresu samodzielności pacjentowi przyznaje się 0-100 punktów. llość uzyskanych punktów świadczy o stopniu deficytu sprawności i określa jego stan oraz zapotrzebowanie na opiekę. Sprawność podopiecznych można było różnicować w zależności od przedziałów punktowych, do jakich zostali zakwalifikowani: 86-100 punktów - pacjent dobrze radzi sobie z czynnościami życia codziennego; 21-
85 punktów - pacjent częściowo nie radzi sobie z czynnościami życia codziennego; 0-20 punktów - pacjent nie potrafi samodzielnie wykonać większości czynności życia codziennego [18].

Oceny przydatności kwestionariusza Barthel w warunkach polskiej opieki zdrowotnej jako wiarygodnego narzędzia (współczynnik $\alpha$-Cronbacha 0,78 $\div 0,89$; współczynnik korelacji test-retest $0,93 \div 0,95$ ) do mierzenia zakresu samodzielności w wykonywaniu czynności życia codziennego przez osoby starsze zostały potwierdzone $w$ badaniach Kuźmicz i wsp. [19].

\section{Wymagania bioetyczne badań}

Na prowadzenie badań uzyskano pisemną zgodę menedżerów i dyrektorów poszczególnych zakładów opieki zdrowotnej, w których pracowały pielęgniarki opieki długoterminowej. Wszyscy uczestnicy badania (opiekunowie nieformalni oraz pacjenci) wyrazili świadomą pisemną zgodę. Badanie zostało przeprowadzone po uzyskaniu pozytywnej opinii Komisji Bioetycznej przy Uniwersytecie Medycznym w Lublinie (Nr KE-0254/13./2016) i zgodnie z wymaganiami Deklaracji Helsińskiej.

\section{Analiza statystyczna}

Pozyskane dane poddano analizie statystycznej przy wy korzystaniu programu IBM SPSS Statistics (wersja 20). Zmienne zostały podsumowane przy użyciu standardowych statystyk opisowych, takich jak średnie (M), mediana (Me), odchylenia standardowe (SD) i częstotliwości. W celu ustalenia związku pomiędzy zmiennymi mierzonymi na skali ilościowej zastosowano współczynnik korelacji r Pearsona. Przed zastosowaniem tego współczynnika przeanalizowano rozkłady zmiennych: skośność i kurtoza mieściła w przedziale $(-1 ; 1)$. W przypadku zmiennych porządkowych lub zmiennych, których rozkłady nie spełniały warunków zastosowania r Pearsona, zastosowano współczynnik korelacji rho Spearmana. Do ustalenia związku pomiędzy zmienną ilościową, a zmienną dychotomiczną zastosowano współczynnik korelacji punktowo-biseryjnej. Przyjęto istotność statystyczną na poziomie $p<0,05$.

\section{Wyniki}

\section{Charakterystyka opiekunów nieformalnych}

Wśród opiekunów większość osób stanowiły kobiety (75,3\%). Średni wiek badanych wynosił 57,69 lat (SD = 12.9), najmłodszy opiekun był w wieku 26 lat, a najstarszy 84 lat. Analiza kategorii wiekowych opiekunów wskazuje, że liczba opiekunów wrasta w każdej kolejnej grupie wiekowej: do 65 r.ż. (od 2-20\% opiekunów), jednak najwięcej opiekunów (34,7\%) jest w grupie wiekowej 56-65 lat. 
Zdecydowana większość opiekunów (68,7\%) deklarowała życie w związku małżeńskim/partnerskim. Rolę opiekuna nieformalnego najczęściej pełniły dzieci osób objętych opieką długoterminową $(46,7 \%)$ oraz współmałżonkowie (22\%), z kolei $15,5 \%$ opiekunów nie miało żadnego pokrewieństwa z pacjentem. Około $4 \%$ badanych opiekunów stanowili inni członkowie rodziny pacjentów. Dla prawie połowy opiekunów $(47,3 \%)$ biernych zawodowo głównym źródłem dochodów była emerytura/renta oraz praca w pełnym (34,6\%) oraz niepełnym (8\%) wymiarze godzinowym (Tabela 1). Sprawowanie opieki nad chorym w domu związane było z bliską odległością miejsca zamieszkania opiekuna od pacjenta objętego opieką długoterminową. Najwięcej opiekunów (57,3\%) mieszka razem z pacjentem w tym samym mieszkaniu, w następnej kolejności: 12,7\% opiekunów dojeżdża około 10 minut środkiem lokomocji i 11,3\% mieszkało w odległości krótkiego spaceru.

Tabela 1. Charakterystyka nieformalnych opiekunów pacjentów $\mathrm{z}$ deficytem sprawności funkcjonalnej $(\mathrm{N}=150)$

\begin{tabular}{|c|c|}
\hline \multicolumn{2}{|l|}{ Zmienna } \\
\hline Kobieta & $113(75,3 \%)$ \\
\hline Mężczyzna & $37(24,7 \%)$ \\
\hline \multicolumn{2}{|c|}{ Wiek w latach $(M=57,69 ; S D=12,9)$} \\
\hline $26-35$ & $11(7,3 \%)$ \\
\hline $36-45$ & $15(9,3 \%)$ \\
\hline $46-55$ & $31(20,0 \%)$ \\
\hline $56-65$ & $52(34,7 \%)$ \\
\hline $66-75$ & $31(20,7 \%)$ \\
\hline 76 i powyżej & $10(6,7 \%)$ \\
\hline \multicolumn{2}{|c|}{ Stan cywilny } \\
\hline $\begin{array}{l}\text { Wolny } \\
\text { W związku }\end{array}$ & $\begin{array}{c}47(31,3 \%) \\
103(68,7 \%)\end{array}$ \\
\hline \multicolumn{2}{|c|}{ Miejsce zamieszkania } \\
\hline Miasto & $140(93,9 \%)$ \\
\hline Wieś & $9(6,1 \%)$ \\
\hline \multicolumn{2}{|c|}{ Stopień pokrewieństwa z podopiecznym } \\
\hline Współmałżonek & $33(22,0 \%)$ \\
\hline Rodzic & $70(46,7 \%)$ \\
\hline Rodzeństwo & $4(2,7 \%)$ \\
\hline Dziecko & $2(1,3 \%)$ \\
\hline Synowa/zięć & $7(4,7 \%)$ \\
\hline Inny członek rodziny & $6(4,0 \%)$ \\
\hline Przyjaciel/sąsiad & $5(3,3 \%)$ \\
\hline Brak pokrewieństwa & $23(15,3 \%)$ \\
\hline \multicolumn{2}{|c|}{ Aktywność zawodowa } \\
\hline Pełny etat & $52(34,6 \%)$ \\
\hline Niepełny etat & $12(8,0 \%)$ \\
\hline Umowa zlecenie & $6(4,0 \%)$ \\
\hline Emerytura/renta & $73(48,6 \%)$ \\
\hline Bezrobotna/y & $6(4,0 \%)$ \\
\hline Student/ka & $1(0,7 \%)$ \\
\hline
\end{tabular}

Charakterystyka pacjentów domowej opieki pozostających pod opieką opiekunów nieformalnych

W grupie pacjentów $(n=149)$ objętych domową opieką długoterminową z deficytem sprawności funkcjonalnej według skali Barthel (0-85 pkt) było 76,5\% kobiet oraz $23,5 \%$ mężczyzn. Rozpiętość wiekowa badanej grupy wynosiła od 58 lat do 104 lat, średnia wieku 74,91 $(\mathrm{SD}=9,08)$. W większości były to osoby zamieszkujące w mieście $(93,9 \%)$ oraz osoby w stanie cywilnym wolnym (65,1\%). Wszyscy pacjenci byli objęci opieką domową, z której średnio korzystali 3,59 lat $(S D=2,68)$. Średnia ocena sprawności funkcjonalnej u pacjentów wg skali Barhel wynosiła 43,2 (SD = 27,06). Najliczniejszą grupę 68 osób $(45,6 \%)$ stanowili pacjenci w ocenie skalą Barthel z punktacją 21-40 oraz pacjenci z punktacją 0-20 (32,9\%; $n=49$ ).

Średnia liczba leków przepisanych przez lekarza i przyjmowanych przez pacjentów wynosi 7,9 (SD $=2,8)$. Badani pacjenci charakteryzują się wielochorobowością, dominują schorzenia reumatologiczne (77,9\%), narządów zmystów (65,1\%), psychiatryczne (51,7\%), endokrynologiczne $(45 \%)$, układu oddechowego (19,5\%) oraz układu nerwowego (18,5\%). Większość badanych pacjentów opieki długoterminowej pozytywnie oceniła sprawowaną nad nimi opiekę: bardzo dobrze (64\%), dobrze (24\%), dostatecznie i źle (5,4\%). 6,6\% ankietowanych nie udzieliło odpowiedzi.

\section{Samoocena stanu zdrowia i doświadczenie związane z opieką opiekunów nieformalnych} Większość opiekunów ocenia stan swojego zdrowia jako zły (41,3\%), przeciętny (34\%) oraz bardzo zły (12,7\%). Samoocena bardzo dobrego i dobrego stanu zdrowia dotyczy pozostałych 11,3\% opiekunów. Ponad połowa badanej grupy opiekunów $(53,3 \%)$ ma doświadczenie w opiekowaniu się, gdyż pacjent, którym się obecnie zajmuje jest już kolejną osobą, którą się opiekuje. Z kolei dla 41,3\% badanych opiekunów podopieczni są pierwszymi, z którymi pracują. Średnia liczba godzin poświęconych tygodniowo na opiekę nad pacjentem przez opiekuna wynosi 34,78 godzin $(S D=45,04)$, natomiast inne osoby zaangażowane $\mathrm{W}$ opiekę nad pacjentem poświęcają średnio 19,69 godzin $(S D=28,4)$ tygodniowo na sprawowanie opieki nad chorym w opiece długoterminowej (Tabela 2).

M - średnia arytmetyczna, SD - odchylenie standardowe 
Tabela 2. Doświadczenie opiekunów związane z opieką nad podopiecznym w domu

\begin{tabular}{|c|c|}
\hline Zmienne & $\mathrm{n}(\%)$ \\
\hline \multicolumn{2}{|c|}{ Doświadczenie w opiece } \\
\hline Pierwsza osoba, którą się opiekuje & $62(41,3)$ \\
\hline Kolejna osoba, którą się opiekuje & $80(53,3)$ \\
\hline $\begin{array}{l}\text { Praca na co dzień z pacjentami } \\
\text { objętymi opieką domową }\end{array}$ & $7(4,7)$ \\
\hline $\begin{array}{l}\text { Posiadanie kursu dla opiekunów } \\
\text { medycznych }\end{array}$ & $1(0,7)$ \\
\hline $\begin{array}{l}\text { Średni czas poświęcony na opiekę } \\
\text { nad pacjentem tygodniowo przez } \\
\text { opiekuna nieformalnego } \\
\text { (w godzinach); }(n=139)\end{array}$ & $M=34,78(S D=45,04)$ \\
\hline $\begin{array}{l}\text { Średni czas poświęcony na opiekę } \\
\text { nad pacjentem tygodniowo przez } \\
\text { inne osoby wspierające opiekunów } \\
\text { (w godzinach); }(n=72)\end{array}$ & $M=19,69(S D=28,4)$ \\
\hline
\end{tabular}

\section{Obciążenie opiekunów nieformalnych według COPE-Indeks}

Oceny obciążenia opiekuna rodzinnego dokonano oddzielnie dla każdej z analizowanych domen COPE-Indeks. Wartość mediany w skali NWO, równa Me $=11$ punktów, posłużyła do dychotomizacji badanych na grupę mniej (7-10 punktów) i bardziej obciążonych opieką (11-28 punktów). W subskali PWO wartość mediany równa 14 pkt, pozwoliła na wyodrębnienie badanych o niskim wskaźniku PWO (4-13 punktów) oraz wyższym wskaźniku (14-16 punktów). W subskali JW wartość mediany 13 pkt posłużyła do dychotomizacji badanych na grupę o niższym (4-12 pkt) i wyższym (13-16 pkt) wskaźniku jakości wsparcia. Średnia wartość w obszarze NWO wyniosła 11,80 (SD $=3,75)$ i świadczy o przeciążeniu opiekuna w związku z opieką nad pacjentem. W domenie PWO średnia wyniosła 13,71 (SD $=2,07)$, natomiast $w$ jakości wsparcia JW $M=12,46$ (SD = 2,69). Wyniki obu domen PWO i JW wskazują, że mimo obciążenia opieką, opiekunowie rodzinni czerpią pozytywne wartości ze sprawowanej opieki. Wyniki przedstawia tabela 3.

Tabela 3. Statystyki opisowe dotyczące obciążenia opiekuna w poszczególnych subskalach COPE Indeks

\begin{tabular}{|l|c|c|c|c|c|c|}
\hline \multicolumn{1}{|c|}{$\begin{array}{c}\text { Subskale } \\
\text { COPE-Indeks }\end{array}$} & M & Me & SD & Min. & Max. & $\begin{array}{c}\text { Zakres } \\
\text { punktowy } \\
\text { subskali }\end{array}$ \\
$\begin{array}{l}\text { Negatywny Wpływ } \\
\text { Opieki (NWO) } \\
\begin{array}{l}\text { Pozytywna Wartość } \\
\text { Opieki (PWO) } \\
\text { Jakość Wsparcia (JW) }\end{array}\end{array}$ & 11,80 & 11,00 & 3,75 & 7,00 & 23,00 & $7-28$ \\
\hline
\end{tabular}

M - średnia arytmetyczna, Me - mediana, SD - odchylenie standardowe
Obciążenie opiekunów nieformalnych wg COPEIndeks a zmienne socjodemograficzne i zmienne organizacjno-zdrowotne

Wyniki analizy korelacji pomiędzy subskalami COPE-Index, a zmiennymi socjodemograficznymi wykazują, że domeny PWO i JW pozostają w niskiej, ale istotnej statystycznie korelacji $(p<0,05)$ z płcią żeńską opiekuna. Jakość wsparcia dawanego przez opiekunów spoza najbliższego kręgu rodziny koreluje z niższym jej poziomem $(p<0,01)$. Wyniki prezentuje tabela 4

Tabela 4. Zmienne socjodemograficzne oraz zdrowotno-organizacyjne opiekuna a subskale COPE-Indeks

\begin{tabular}{|l|c|c|c|}
\multicolumn{1}{|c|}{$\begin{array}{c}\text { Zmienne } \\
\text { Wybrane zmienne socjodemograficzne } \\
\text { NWO }\end{array}$} & $\begin{array}{c}\text { Subskala } \\
\text { PWO }\end{array}$ & $\begin{array}{c}\text { Subskala } \\
\text { JW }\end{array}$ \\
Płeć opiekuna & $-0,14$ & $0,161^{*}$ & $0,205^{*}$ \\
Wiek opiekuna & 0,1 & $-0,09$ & $-0,002$ \\
Stan cywilny & 0,133 & $-0,038$ & $-0,006$ \\
Pokrewieństwo & 0,102 & $-0,156$ & $-0,286^{* *}$ \\
Miejsce zamieszkania & $-0,058$ & $-0,112$ & $-0,052$ \\
\multicolumn{3}{|c}{ Wybrane zmienne zdrowotno-organizacyjne } \\
Samoocena zdrowia opiekuna & $-0,370 * *$ & $0,303^{* *}$ & $0,263^{* *}$ \\
Doświadczenie w opiece & $-0,146$ & 0,153 & 0,137 \\
Czas opieki opiekuna & $0,413^{* *}$ & $-0,179 *$ & $-0,352^{* *}$ \\
Czas opieki innej osoby & 0,074 & 0,017 & $-0,093$ \\
Wsparcie w opiece innej osoby & $-0,081$ & $-0,021$ & $0,169 *$
\end{tabular}

*korelacja istotna na poziomie $0,05, * *$ korelacja istotna na poziomie 0,01

Wysoką istotność statystyczną $(p<0,01)$ stwierdzono w obszarze wszystkich domen COPE-Indeks w zależności od samooceny stanu zdrowia opiekuna. Wraz z pogorszeniem się stanu zdrowia opiekuna wzrasta przeciążenie opieką (NWO), maleje pozytywna wartość opieki (PWO) i jakość wsparcia (JW). Ponadto, wraz ze wzrostem czasu opieki wyraźnie wzrasta korelacja z przeciążeniem opieką $w$ domenie NWO $(p<0,01)$, natomiast maleje satysfakcja z opieki (PWO) $(p<0,05)$ ijakość doświadczonego wsparcia ze strony pomocy formalnej i nieformalnej (JW) $(p<0,01)$. Wzrost wsparcia innych osób w opiece nad pacjentem koreluje z obszarem jakości wsparcia (JW) $(p<0,05)$. Starszy wiek pacjenta koreluje wysoce istotnie statystycznie $z$ domeną NWO $(p<0,01)$, natomiast domeny PWO $(p<0,05)$ i JW ( $p<0,01)$ u opiekuna maleją wraz z wiekiem pacjenta przy przeciętnej sile zależności (Tabela 5). 
Tabela 5. Zmienne socjodemograficzne pacjenta a subskale COPEIndeks

\begin{tabular}{|l|c|c|c|}
\multicolumn{1}{|c|}{ Zmienne } & $\begin{array}{c}\text { Subskala } \\
\text { NWO }\end{array}$ & $\begin{array}{c}\text { Subskala } \\
\text { PWO }\end{array}$ & $\begin{array}{c}\text { Subskala } \\
\text { JW }\end{array}$ \\
\hline Płeć & 0,075 & $-0,163^{*}$ & 0,007 \\
Wiek & $0,263^{* *}$ & $-0,181^{*}$ & $-0,322^{* *}$ \\
Stan & $-0,094$ & 0,04 & 0,157 \\
cywilny & $-0,04$
\end{tabular}

*korelacja istotna na poziomie $0,05, * *$ korelacja istotna na poziomie 0,01

\section{Dyskusja}

Rodzina i jej członkowie jako opiekunowie nieformalni są najpowszechniejszym i najważniejszym dostawcą usług opiekuńczych w Polsce pomimo wsparcia jakie otrzymuje pacjent z zakresu pielęgniarskiej opieki długoterminowej. Osobą, która najczęściej pełni rolę głównego opiekuna jest najbliższy członek rodziny. W badaniach własnych opiekunowie nieformalni $(n=150)$ w opiece nad pacjentami z deficytem sprawności funkcjonalnej wg skali Barthel 0-85 pkt wyrażają przeciążenie opieką w subskali NWO $(\mathrm{M}=11,80 ; \mathrm{SD}=3,75)$ według COPE-Indeks. $\mathrm{W}$ badaniach Karczewskiej i wsp. [20] w dwóch grupach opiekunów nieformalnych: grupa I - sprawujących opiekę nad podopiecznymi z otępieniem i zaburzeniami poznawczymi ( $n=311)$, gdzie średni wynik w skali Barthel podopiecznych wynosił 62,7 (SD = 32,5) oraz grupa II - grupa referencyjna opiekunów $(n=686)$, gdzie średni wynik w skali Barthel podopiecznych wynosił 86,7 (SD = 18,4), średni wynik w skali NWO $w$ grupie pierwszej miał wartość 11,9 (SD = $4,2)$ vs. grupy drugiej $M=8,9(S D=2,7)$. Uzyskane wyniki w badaniach własnych pozostają w wartościach zbliżonych do grupy opiekunów nieformalnych, sprawujących opiekę nad podopiecznymi z otępieniem, pomimo że wskaźnik sprawności funkcjonalnej w tej grupie był zdecydowanie wyższy niż w naszej grupie badanych pacjentów domowej opieki ( $M=43,20 ; S D=27,06)$. Niezależnie od powodu świadczenia opieki przez opiekuna nieformalnego czas jej trwania sięgał niemal 6 lat w badaniach Karczewskiej i wsp. [20], natomiast w badaniach własnych średni czas objęcia pacjentów opieką długoterminową domową wynosit 3,59 lat $(S D=2,68)$.

Z badań Wojszel [21] wynika, że 44,9\% opiekunów na wsi i 57,3\% w mieście często lub czasami czuła się przeciążona obowiązkami opiekuńczymi. Wśród nich 79,4\% w mieście i aż 90,1\% na wsi, co najmniej czasami odczuwała satysfakcję z pełnionej opieki. Wyniki badań własnych wskazują także, że opiekunowie nieformalni w ocenie subskali NWO według COPE-Indeks odczuwają negatywne przeciążenie w związku z opieką nad pacjentem z deficytem sprawności funkcjonalnej, jakkolwiek wyrażają także satysfakcjonujące odczucia w zakresie pozytywnej wartości opieki (PWO) i jakości wsparcia (JW) ze sprawowanej opieki, co niewątpliwie potwierdza satysfakcję z pełnionej roli. W dokonanym przeglądzie literatury przy użyciu skali COPE-Indeks nie odnaleziono innych badań, z zastosowaniem subskal PWO i JW ze sprawowanej opieki. Natomiast niektórzy Autorzy przy użyciu kwestionariuszy autorskich badali poczucie satysfakcji opiekunów nieformalnych z pełnionej opieki, co można odnieść do odczucia pozytywnej wartości opieki w badaniach własnych. W wynikach badań Grochowskiej [7] opiekunów nieformalnych $(n=64)$ sprawujących nieodpłatną opiekę nad starszą osobą powyżej 65. roku życia dotyczących poczucia satysfakcji oraz obciążenia obowiązkami opieki w zależności od poziomu sprawności podopiecznych wg ADL nie stwierdzono zależności pomiędzy sprawnością podopiecznego, a poczuciem satysfakcji opiekuna ze sprawowanej opieki. Naukowcy z międzynarodowego projektu EUROFAMCARE wysnuli wniosek, że "o ile satysfakcja z opieki nie zmienia się zależnie od poziomu niesprawności podopiecznego w całej próbie badawczej, to obciążenie związane z wykonywaniem czynności opiekuńczych istotnie wzrasta wraz z pogorszeniem się stanu zdrowia i sprawności podopiecznego [22].

W procesie sprawowania opieki nieformalnej wobec podopiecznych potrzebujących pomocy i wsparcia osobami, które najczęściej sprawują taką opiekę, są kobiety. W badaniach Bień i wsp. [22] 79,2\% opiekunów należy do rodziny podopiecznego. W większości analizowanych prac autorzy podkreślają dominację kobiet wśród opiekunów osób w podeszłym wieku. U Karczewskiej i wsp. [20] kobiety - opiekunki stanowiły 87,1\% badanych, u Piłat [23] - 62,5\%, zaś u Wojszel i Bień [24] - 79,7\%, a w wynikach badań Zysnarskiej i wsp. [25] - 80,17\% stanowiły respondentki. W wynikach badań własnych kobiety stanowiły 75,3\% grupy opiekunów nieformalnych. Dane z europejskiego projektu EUROFAMCARE z 2006 roku charakteryzują opiekunów nieformalnych w następujący sposób: są to głównie kobiety (76\%), ich średni wiek wynosi 55 lat, a 56\% mieszka w tym samym gospodarstwie domowym (lub w tym samym budynku) co podopieczny [26]. W Polsce w większości przypadków usługi domowej opieki długoterminowej są wykonywane przez kobiety, które do roli opiekunek najpierw przygotowują się jako matki ( $w$ wieku 30-40 lat), a następnie pełnią opiekę nad starszymi rodzicami i teściami (w wieku 50-60 lat) [27].

Wyniki naszych badań wnoszą kolejną ważna informację związaną z obecnością opiekuna nieformalnego płci żeńskiej. Stwierdzono bowiem, że pozytywna wartość opieki (PWO) ijakość wsparcia (JW) w subskalach COPE-In- 
deks koreluje z płcią żeńską opiekunów nieformalni, natomiast jakość dawanego wsparcia maleje wraz ze spadkiem stopnia pokrewieństwa osoby opiekuna z podopiecznym. Informacja ta jest niewątpliwie ważna z punktu widzenia organizacji instytucjonalnych form wspierających opiekę nieformalną, nie tylko z punktu widzenia kosztów opieki, ale także jej wysokiej jakości.

Kolejnym ważnym aspektem analizy obciążenia opiekuna nieformalnego obowiązkami opieki domowej jest kwestia stanu zdrowia opiekunów, z uwzględnieniem ich wieku. W badaniach własnych średnia wieku opiekunów nieformalnych wynosiła 57,69 lat (SD $=12,9$ ), a większość opiekunów oceniło stan swojego zdrowia jako zły (41,3\%), przeciętny (34\%) oraz bardzo zły (12,7\%). W badaniach Zysnarska i wsp. [25] w samoocenie stanu zdrowia tylko 23,6\% kobiet czuło się bardzo dobrze lub dobrze. Respondentki podkreślały również występowanie licznych dolegliwości bólowych (dotyczących najczęściej kręgosłupa, stawów i głowy). Tylko 35,05\% badanych nie odczuwa permanentnego bólu. W badaniach Bień i wsp. [28] stwierdzono, że 30\% opiekunów swój stan zdrowia oceniło jako dobry i bardzo dobry. Swoje zdrowie jako złe i bardzo złe oceniło $15 \%$ respondentów. W wynikach badań Karczewskiej i wsp. [20] średni wiek opiekunów nieformalnych $w$ grupie podopiecznych z otępieniem $(n=311)$ wynosił 53,9 lat $(S D=14,1)$, a w grupie referencyjnej $(n=689)$ - 49,6 lat (SD $=14,8)$, natomiast osoby ze złą samooceną stanu zdrowia stanowiły w grupie pierwszej $17,7 \%$ vs. $8,5 \%$ grupy drugiej.

W badaniach własnych stwierdzono także, że nasilenie przeciążenia opieką (w subskali NWO wg COPE-Index) nad pacjentem w opiece domowej rośnie wraz ze gorszą ocena stanu zdrowia opiekuna. W wynikach badań BienBarkowska i wsp. [29] autorzy stwierdzają, że subiektywne postrzeganie własnego stanu zdrowia opiekuna nieformalnego jest niezależnie związane z prawdopodobieństwem obciążenia z powodu opieki. Jeśli opiekun nieformalny "czasami” czuje się dobrze wspierany , „czasami” radzi sobie dobrze jako opiekun i postrzega swoje zdrowie jako "złe" lub „bardzo złe", może nie odczuwać wysokiego obciążenia opieką w subskali NWO wg COPE-Indeks. Spostrzeżenie to niewątpliwie potwierdza pozytywną wartość opieki, jaką doświadczają opiekunowie pomimo istniejącego przeciążenia opieką.

Przy istotnym przyroście populacji osób starszych, osób z mniejszą sprawnością funkcjonalna w Polsce, zwraca uwagę niedostatek rozwiązań systemowych, w tym brak wystarczającego wsparcia psychoedukacyjnego, emocjonalnego dla opiekunów nieformalnych. Adekwatne rozwiązania systemowe ukierunkowane na kompleksową redukcję obciążenia kluczowych opiekunów (rodzin) mogą przyczynić się do sprawniejszego pełnienia przez nich ich funkcji, a przez to odroczyć konieczność delegowania opieki do instytucji, jednocześnie zmniejszając wydatki na ten cel z budżetu państwa [16, 30].

\section{Wnioski}

1. Opiekunowie nieformalni w ocenie według COPE-Indeks odczuwają negatywne przeciążenie w związku z opieką nad pacjentem z deficytem sprawności funkcjonalnej, jakkolwiek wyrażają także satysfakcjonujące odczucia w zakresie pozytywnej wartości opieki i jakości wsparcia ze sprawowanej opieki.

2. Pozytywna wartość opieki i jakość wsparcia koreluje z płcią żeńską opiekunów nieformalnych, natomiast jakość dawanego wsparcia maleje wraz ze spadkiem stopnia pokrewieństwa osoby opiekuna z podopiecznym.

3. Nasilenie przeciążenie opieką nad pacjentem w opiece domowej rośnie wraz ze gorszą ocena stanu zdrowia opiekuna oraz maleje jednocześnie pozytywna wartość opieki i jakości wsparcia dawanego przez opiekuna rodzinnego/nieformalnego.

4. Starszy wiek pacjenta, którym zajmuje się opiekun koreluje z negatywnym wpływem opieki na opiekuna oraz ze spadkiem pozytywnej wartości opieki i jakość wsparcia dawanego przez opiekuna rodzinnego/nieformalnego.

\section{Oświadczenia}

Oświadczenie dotyczące konfliktu interesów

Autorzy deklarują brak konfliktu interesów.

\section{Źródła finansowania}

Praca została sfinansowana z środków własnych Uniwersytetu Medycznego w Lublinie w ramach działalności statutowej na utrzymanie potencjału badawczego (DS 519)

\section{Piśmiennictwo}

1. Kosińska M, Kułagowska E, Niebrój L, Stanisławczyk D. Obciążenia opiekunów osób zakwalifikowanych do opieki dłu goterminowej domowej. Med Środow. 2013; 16(2): 59-68.

2. Kędziora-Kornatowska K, Muszalik M, Skolmowska E. Pielęgniarstwo w opiece długoterminowej. Warszawa: PZWL; 2010

3. Strzelecka E. Szkolenie opiekunów osób starszych wobec nowych wyzwań na rynku pracy. Acta Uniwersitatis Lodziensis Folia Oeconomika 2015; 312(2): 127-150.

4. Kotowska I, Wóycicka IE (red.). Sprawowanie opieki oraz inne uwarunkowania podnoszenia aktywności zawodowej osób w starszym wieku produkcyjnym. Raport z badań. Warszawa: Departament Analiz Ekonomicznych i Prognoz Ministerstwo Pracy i Polityki Społecznej; 2008.

5. Golinowska S. Społeczno-ekonomiczne konsekwencje starzenia się populacji. (W:) Kleer J (red.). Konsekwencje eko- 
nomiczne i społeczne starzenia się społeczeństwa. Warszawa: PAN; 2008. 35

6. Markiewicz I, Cebulak M. Sprawność funkcjonalna pacjentów objętych domową długoterminową opieką pielęgniarską. Probl Pielęg. 2014; 22(1): 42-51.

7. Grochowska J. Poczucie satysfakcji oraz obciążenia obowiązkami nieformalnych opiekunów osób starszych w zależności od poziomu sprawności podopiecznych. MONZ. 2014; 20(1): 46-50.

8. Grabowska-Fudala B, Jaracz K, Smelkowska A, Pniewska J, Buczkowska M. Obciążenie osób sprawujących opiekę nad osobami z chorobą Alzheimera. Wyniki wstępne. Now Lek. 2013; 82(1): 25-30.

9. Pinquart M, Sörensen S. Differences between caregivers and noncaregivers in psychological health and physical health: a meta-analysis. Psychol Aging. 2003; 18(2): 250-267.

10. Ganapathy V, Graham GD, DiBonaventura MD, Gillard PJ, Goren A, Zorowitz RD. Caregiver burden, productivity loss, and indirect costs associated with caring for patients with poststroke spasticity. Clin Interv Aging. 2015; 6(10): 1793-1802

11. Principi A, Lamura G, Sirolla C, Mestheneos L, Bień B, Brown J, et al. Work restrictions experienced by midlife family caregivers of older people. Ageing Soc. 2014; 34(2): 209-231.

12. Bauer JM, Sousa-Poza A. Impacts of informal caregiving on caregiver employment, health, and family. J Popul Ageing. 2015; 8(3): 113-145.

13. Adelman RD, Tmanova LL, Delgado D, Dion S, Lachs MS. Caregiver burden. A clinical review. JAMA. 2014; 311(10): 1052-1059.

14. Rachel W, Datka W, Zyss T, Zięba A. Obciążenie opiekunów pacjentów z otępieniem w chorobie Alzheimera. Gerontol Pol. 2014; 22(1): 14-23.

15. Kim H, Chang M, Rose K, Kim S. Predictors of caregiver burdenin caregivers of individuals with dementia. J Adv Nurs. 2012; 68(4): 846-855.

16. Ciałkowska-Kuźmińska M, Kasprzak M. Obciążenie opiekunów jako czynnik delegowania opieki do instytucji psychogeriatrycznych. Psychogeriatria Polska 2012; 9(2): 69-76.

17. Balducci C, Mnich E, McKee KJ, Lamura G, Beckmann A, Krevers $B$, et al. Negative impact and positive value in caregiving: validation of the COPE index in a six-country sample of carers. Gerontologist. 2008; 48(3): 276-286.

18. Mahoney Fl, Barthel D. Functional evaluation: the Barthel Index. Maryland State Medical Journal 1965; 14: 56-61.

19. Kuźmicz I, Brzostek T, Górkiewicz M. Kwestionariusz Barthel jako narzędzie pomiaru zakresu samodzielności fizycznej osób w podeszłym wieku. Stud Med. 2008; 12: 17-21.

20. Karczewska B, Bień B, Ołdak E, Jamiołkowski J. Opiekunowie rodzinni osób starszych z otępieniem lub zaburzeniami poznawczymi w Polsce - czynniki ryzyka obciążenia opieką. Gerontol Pol. 2012; 20(2): 59-67.
21. Wojszel ZB. Geriatryczne zespoły niesprawności i usługi opiekuńcze w późnej starości. Analiza wielowymiarowa na przykładzie wybranych środowisk województwa podlaskiego. Białystok: Trans Humana; 2006.

22. Bień B, Wojszel ZB, Doroszkiewicz H. Poziom niesprawności osób w starszym wieku jako wskazanie do wspierania opiekunów rodzinnych. Gerontol Pol. 2008; 16(1): 25-34.

23. Piłat A. Rodzinni opiekunowie osób starszych. Zeszyty Pracy Socjalnej 2016; 21(1): 23-33.

24. Wojszel Z, Bień B. Czynniki determinujące obciążenie opiekuna rodzinnego osoby starszej w Polsce. (W:) Halicka M, Halicki J (red.). Zostawić ślad na ziemi. Białystok: Wydawnictwo Uniwersytetu w Białymstoku; 2006. 338-350.

25. Zysnarska M, Wojnicz-Michera I, Taborowska M, Kołecki P, Maksymiuk T. Kobieta - opiekun osoby przewlekle chorej wyznaczniki przeciążenia. Now Lek. 2010; 79(5): 386-391.

26. Servives for supporting family carers of elderly people in Europe: characteristics, coverage and usage. Examples of good and innovative practices in supporting family carers in Europe. The EUROFAMCARE consorcium, http://www.uke.de/ex tern/eurofamcare/documents/deliverables/good_practice. pdf (data dostępu: 05.01.2018).

27. Wóycicka I, Rurarz R. Zapotrzebowanie na opiekę. (W:) Kotowska IE, Sztanderska U, Wóycicka I (red.). Aktywność zawodowa i edukacyjna a obowiązki rodzinne. Warszawa: Wydawnictwo Naukowe Scholar; 2007.

28. Bień B, Wojszel ZB, Wilmańska J, Sienkiewicz J. Starość pod ochroną. Opiekunowie rodzinni niesprawnych osób starych w Polsce - porównawcze studium środowiska miejskiego i wiejskiego w Polsce. Kraków: Oficyna Wydawnicza TEXT; 2001.

29. Bień-Barkowska K, Doroszkiewicz H, Bień B. Silent strain of caregiving: exploring the best predictors of distress in family carers of geriatric patients. Clin Interv Aging. 2017; 12(2): 263-274

30. Buckner L., Yeandle S. Valuing Carers 2011: Calculating the value of carers' support. Carers UK, Report; 2011, 2.

Zaakceptowano do edycji: 20.08 .19 Zaakceptowano do publikacji: 26.09.19

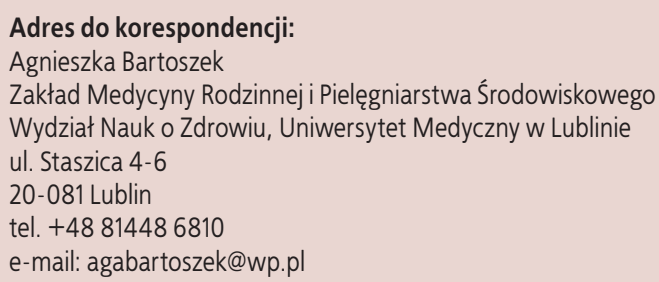

